\title{
THE CEREBRO-OCULAR-RENAL DYSTROPHIES: A NEW VARIANT
}

\author{
BY \\ R. A. McCANCE, W. J. MATHESON, G. A. GRESHAM and J. R. ELKINTON \\ From the Medical Research Council Department of Experimental Medicine, University of Cambridge and the Children's \\ Hospital, Leicester Royal Infirmary
}

(RECEIVED FOR PUBLICATION AUGUST 31, 1959)

Under this title it is proposed to describe a syndrome which has been under observation in two brothers, both of whom have now died. The syndrome is characterized clinically by anorexia, failure to grow, muscular hypotonia, corneal opacities and mental retardation; and physiologically by a severe hyperchloraemic acidosis, a very acid urine and a noteworthy defect on the part of the kidney to excrete ammonium ions. Progressive renal deterioration has been the cause of death. The disease thus belongs in a way to that ill-defined group described by Lowe, Terry and MacLachlan (1952), Royer and Prader (1957), Debré, Royer, Lestradet and Straub (1955) and also perhaps Goldbloom, Fraser, Waugh, Aronovitch and Wiglesworth (1957). It differs from all of them, however, in the nature of the renal lesion. It has been possible to make clinical, biochemical and post mortem investigations which will each to some extent be considered separately.

\section{Clinical Histories and Biochemical Findings}

The Family. The two patients were brothers, the only children of normal and unrelated English parents. A female sibling was stillborn. Their father has two healthy brothers; their mother a clinically normal sister. Forty other members of the family have been traced without finding any evidence or records of the syndrome.

Case 1 (M), a male child, was born on May 5, 1954. Pregnancy and delivery were normal. His weight at birth was $2.4 \mathrm{~kg}$. and the circumference of his skull $32.5 \mathrm{~cm}$. He was breast fed for three months, but from the start took his food badly, and showed an increasing tendency to vomit from the age of 3 months. He was brought to the hospital at Leicester on account of his eyes and there he was found to have corneal opacities, nystagmus and intense photophobia. He failed to reach the normal milestones and was considered very 'backward' and mentally retarded by the age of 6 months. He was, therefore, sent to a London hospital in Decem- ber, 1955, where the diagnosis of blindness, corneal opacities and mental retardation was confirmed. Pneumo-encephalograms, however, disclosed no abnormality. His cerebrospinal fluid (C.S.F.), obtained 20 to $40 \mathrm{~min}$. after the encephalogram was started, contained $110 \mathrm{mg}$. of protein $/ 100 \mathrm{ml}$. and 40 cells $/ \mathrm{c} . \mathrm{mm}$. His renal function was not investigated.

In November, 1956, he was admitted to Leicester Infirmary under W.J.M. for further investigation. By this time he had had one or two major convulsions. He had a little less photophobia but otherwise his mental and ocular abnormalities seemed unchanged. His reflexes were all active and normal. His systolic blood pressure was found to be $145 \mathrm{~mm}$. $\mathrm{Hg}$ by the flush method, but a narrow cuff was used and this figure may have been too high. Blood was withdrawn for examination and the most striking finding was the low concentration of 'total $\mathrm{CO}_{2}$ '. Other results were-serum calcium $10 \mathrm{mg} . / 100 \mathrm{ml}$. and alkaline phosphatase $12.4 \mathrm{King}$ Armstrong units. The findings in the serum and urine a few months later are summarized in Tables 1 and 2 and will be discussed after the clinical histories. The child's renal tract was visualized satisfactorily by intravenous pyelography and appeared to be normal. His urine was consistently very acid and specific gravities of 1017-1018 were reached in concentration tests. Paper chromatography (Dr. H. Bickel) disclosed no abnormal aminoacids and this finding was confirmed a year later in another laboratory (Professor C. E. Dent). This excluded phenyl ketonuria and the amino-acid pattern of his serum, which was also investigated by Professor C. E. Dent, was found to be normal as well. No evidence of cystinosis has been found by any of the tests applied.

He was admitted to Addenbrooke's Hospital, Cambridge, on January 11, 1957, aged $2 \frac{1}{2}$ years. By this time he had had further convulsions. He weighed $8.4 \mathrm{~kg}$. (normal for age $16.0 \mathrm{~kg}$.); his height was $75 \mathrm{~cm}$. (normal $95 \mathrm{~cm}$.), and his skull and chest measurements were both $44 \mathrm{~cm}$. (normal $50 \mathrm{~cm}$.). His fontanelle had closed. He had nystagmus, and an examination of his eyes under general anaesthesia revealed corneal opacities, but no abnormality in his lenses or fundi, and it was considered that he could distinguish light and shade, and probably also recognize shapes. He had some 
TABLE 1

THE CONCENTRATION OF ELECTROLYTES AND OF CERTAIN OTHER SUBSTANCES IN THE SERUM OF THE PARENTS, THE MOTHER'S SISTER AND THE TWO CHILDREN

\begin{tabular}{|c|c|c|c|c|c|c|c|c|c|}
\hline & & $\underset{(\mathrm{mEq} / / 1 .)}{\mathrm{Na}}$ & $\underset{\text { (mEq./l.) }}{\mathrm{K}}$ & $\underset{\text { (mEq./1.) }}{\mathrm{Cl}}$ & $\begin{array}{c}\text { Total } \mathrm{CO}_{2} \\
(\mathrm{mEq} \cdot / \mathrm{l} .)\end{array}$ & $\begin{array}{l}\text { Inorganic } \mathbf{P} \\
\text { (mg./100 ml.) }\end{array}$ & $\begin{array}{c}\text { Creatinine } \\
(\mathrm{mg} . / 100 \mathrm{ml} .)\end{array}$ & $\underset{\text { (mg./100 ml.) }}{\text { Urea }}$ & $\begin{array}{c}\text { Protein } \\
(\mathrm{g} . / 100 \mathrm{ml} .)\end{array}$ \\
\hline $\begin{array}{c}\text { Normal values } \\
\text { sources) }\end{array}$ & $\begin{array}{c}\text { (various } \\
\cdots\end{array}$ & $130-150$ & $4 \cdot 1-5 \cdot 6$ & $98-106$ & $22 \cdot 5-32 \cdot 9 *$ & $\begin{array}{l}2-5 a \\
4-6 c\end{array}$ & $0 \cdot 7-2 \cdot 0$ & $15-40$ & $6 \cdot 5-8 \cdot 2$ \\
\hline $\begin{array}{l}\text { Father } \\
\text { Mother } \quad \text {.. } \\
\text { Maternal aunt } \\
\text { Older child (M) } \\
\text { Younger child (C) }\end{array}$ & $\begin{array}{l}\cdots \\
\cdots \\
\cdots \\
\cdots\end{array}$ & $\begin{array}{l}139 \\
140 \\
150 \\
132 \\
130\end{array}$ & $\begin{array}{l}4 \cdot 4 \\
4 \cdot 3 \\
4 \cdot 1 \\
6 \cdot 5 \\
7 \cdot 6\end{array}$ & $\begin{array}{l}102 \\
105 \\
107 \\
109 \\
110\end{array}$ & $\begin{array}{l}28 \cdot 4 \\
25 \cdot 7 \\
23 \cdot 4 \\
13 \cdot 7 \\
11 \cdot 7\end{array}$ & $\begin{array}{l}3 \cdot \overline{6} \\
\overline{4 \cdot 9} \\
8 \cdot 4\end{array}$ & $\begin{array}{l}1 \cdot 2 \\
0 \cdot 9 \\
1 \cdot 6 \\
1 \cdot 5 \\
-\end{array}$ & $\begin{array}{r}30 \\
24 \\
24 \\
112 \\
100\end{array}$ & $\begin{array}{l}= \\
\overline{7 \cdot 7} \\
6 \cdot 1\end{array}$ \\
\hline
\end{tabular}

* Unpublished data from J. R. Elkinton's laboratory based on 142 determinations in 50 subjects.

$\mathbf{a}=$ adults.

$\mathrm{c}=$ children

TABLE 2

ACID-BASE RELATIONSHIPS IN THE URINE OF NORMAL ADULTS AND BABIES, THE PARENTS, THE MOTHER'S SISTER, THE TWO PATIENTS, AND ADULTS AND CHILDREN WITH TYPICAL RENAL ACIDOSIS

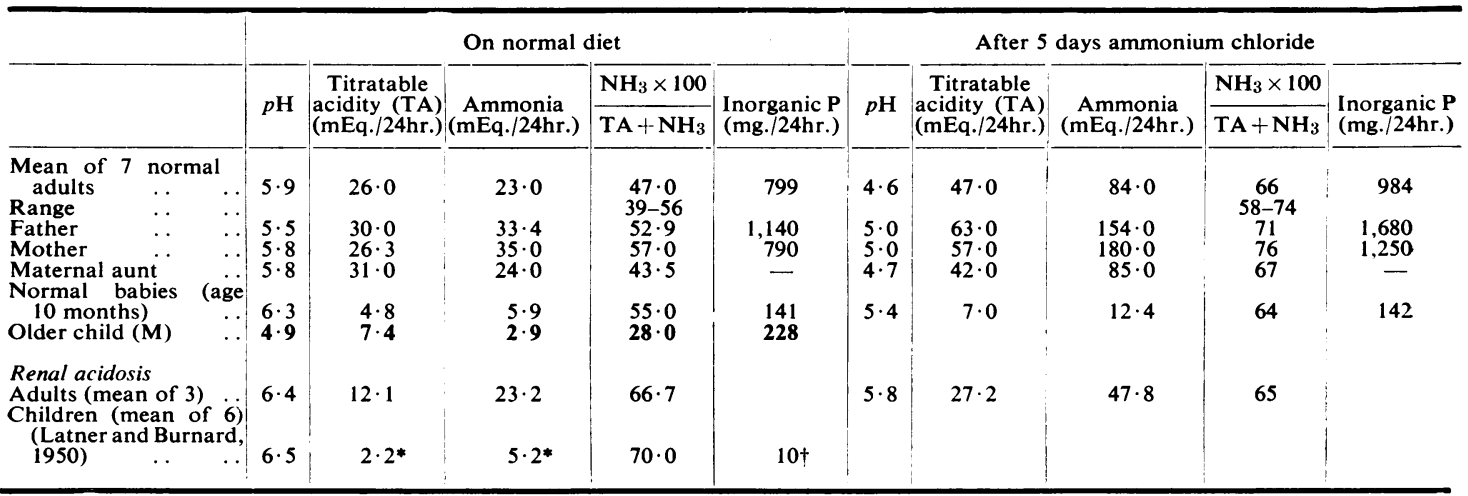

* m. mols. $/ 2 \mathrm{hr}$. $\quad+\mathrm{mg} . / 2 \mathrm{hr}$.

intention tremor and a flexor plantar response. He was unable to sit up unsupported, and his mental achievements were those of a child of $6 \mathrm{mths}$. His blood pressure by auscultation was found to be $95 / 60$. His blood count was quite normal and remained so for the next year. He was examined radiologically with great care by Dr. F. R. Berridge, but nothing characteristic or diagnostic was found.

M. was treated for some time with enough sodium and potassium citrates to raise the total $\mathrm{CO}_{2}$ in his plasma to about $23 \mathrm{mEq} . / 1$. At this level of plasma $\mathrm{CO}_{2}$ he sometimes passed an alkaline urine (Schwartz, Hall, Hays and Relman, 1959), but his blood urea remained raised to between $80-100 \mathrm{mg}$. $/ 100 \mathrm{ml}$., and clinically he did not materially improve. He was discharged on March 7, 1957, readmitted April 5-June 27, again for a few weeks in August-September, and finally in late January, 1958. His weight was then $9 \cdot 1 \mathrm{~kg}$. and his height $86 \mathrm{~cm}$. His physical signs were unchanged, but he had had more vomiting with some diarrhoea and had had more fits. His blood pressure was 120/90 and his blood urea on February 21 was $124 \mathrm{mg} . / 100 \mathrm{ml}$. Gastric juice was removed and found to contain $15 \mathrm{ml}$. $\mathrm{N} / 10 \mathrm{HCl} / 100 \mathrm{ml}$. A lumbar puncture was performed and normal fluid under normal pressure was removed. The amino-acid pattern of this fluid was examined by Professor C. E. Dent and no abnormalities were found. The concentration of glutamine was $7.8 \mathrm{mg} . / 100 \mathrm{ml}$. Dr. J. M. Walshe, who kindly made this determination, considered the figure to be a normal one, as also was the one found for his blood ammonia.

An electro-encephalogram was recorded on February 4. It was reported upon as being very abnormal. No part of the cerebrum appeared to be functioning physiologically, and a lumbar puncture six days before could not be held responsible.

It was considered justifiable at this time to study M.'s reaction to acetazolamide. This was done while he was being treated with citrates and his plasma $\mathrm{CO}_{2}$ was normal. Table 3 shows the results that were obtained after he had been given $188 \mathrm{mg}$. of acetazolamide/day. His urine became alkaline and the total $\mathrm{CO}_{2}$ in his plasma fell from 30 to $16 \mathrm{mEq} . / 1$. The concentration of sodium in his serum fell at the same time from 138 to $127 \mathrm{mEq}$./1. It was concluded that this was the reaction of a person with a normal carbonic anhydrase mechanism in the renal tubules.

The boy was treated with $25 \mathrm{mg}$. of methyl testosterone 
per day from February 14 to March 12 . He improved clinically, gained some weight and became more alert, but his blood urea was $166 \mathrm{mg} . / 100 \mathrm{ml}$. on the last date, and his treatment was then changed to $0.5 \mathrm{mg}$. of $9-\alpha-$ fluorohydrocortisone. Three days later (March 15) he was obviously not so well, had become lethargic and had lost any inclination for food. The concentration of urea in his plasma was found to be $195 \mathrm{mg} . / 100 \mathrm{ml}$. Next day his temperature had risen to $102^{\circ} \mathrm{C}$., pulse to 160 and respirations to $60 / \mathrm{min}$. His blood urea on March 17 was $263 \mathrm{mg} . / 100 \mathrm{ml}$. and his haemoglobin was found to have fallen to $7.5 \mathrm{~g} . / 100 \mathrm{ml}$. He was accordingly given a transfusion of $250 \mathrm{ml}$. of whole blood followed by $100 \mathrm{ml}$. of $\frac{\mathrm{M}}{6}$ sodium lactate since his plasma 'total $\mathrm{CO}_{2}$ ' was only $13 \mathrm{mEq} . / 1$. He passed about $500 \mathrm{ml}$. of urine on March 15 with a specific gravity of 1008. His serum chemistry on March 19 was as follows:

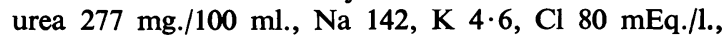
total $\mathrm{CO}_{2} 36.5 \mathrm{mEq}$./1. By this date he was passing very little urine and he died on March 23, 1958.

TABLE 3

THE EFFECT OF ACETAZOLAMIDE ON THE SER UM AND URINE OF THE ELDER SIBLING (M)

\begin{tabular}{|c|c|c|c|}
\hline & Before & Acetazolamide & After Acetazolamide \\
\hline 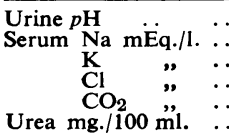 & & $\begin{array}{c}6 \cdot 4 \\
138 \\
6 \cdot 1 \\
100 \\
30 \\
153\end{array}$ & $\begin{array}{c}7 \cdot 8 \\
127 \\
6 \cdot 8 \\
99 \\
16 \\
209\end{array}$ \\
\hline
\end{tabular}

Case 2 (C), the younger brother of $M$. was born on March 1, 1956. He weighed $3 \cdot 1 \mathrm{~kg}$. at birth and the circumference of his skull was $35 \mathrm{~cm}$. He always took his food badly, and by 7 weeks had gained no weight. In the light of his elder brother's records he was suspected at this age of being mentally defective. After a few months he began to have attacks of vomiting. At the age of 7 months he was admitted to the Leicester Royal Infirmary. He weighed at this age $6.5 \mathrm{~kg}$. He was 'floppy' and hypotonic and could not hold his head up, but his reflexes were normal. He did not appear to be blind but had corneal opacities, and did not follow a light with his eyes. His systolic blood pressure by the flush method was $70 \mathrm{~mm}$. $\mathrm{Hg}$; retinal vessels which could be seen were stated to be somewhat attenuated.

Samples of his blood were taken and analysed in November, 1956, and some of the results will be considered later (Table 1). Other findings in the serum at that time were calcium $9.6 \mathrm{mg} . / 100 \mathrm{ml}$, and phosphatase 25.5 King Armstrong units. Samples of his urine were investigated by paper chromatography by Dr. H. Bickel on two occasions for unusual amino acids, but none were found. Several concentration tests were made and the highest specific gravity was 1017 . The $p H$ was consistently low and the lowest figure recorded was 5.0. An intravenous pyelogram was carried out, and both kidneys appeared to excrete the opaque material norm- ally. X-ray photographs showed no signs of osteoporosis or renal calcification.

The child contracted an intercurrent infection with diarrhoea in December, 1956, but death was probably the result of functional renal failure, for his blood urea, shortly before death, was found to have risen to $186 \mathrm{mg}$./ $100 \mathrm{ml}$. on December 26, 1956, and the pulmonary oedema found after death was considered to be uraemic in origin.

\section{Acid-base Records and Comparisons}

Table 1 shows the findings to be expected in a normal serum, and the results which were obtained on investigating the father and mother of the two children, the mother's sister, and the two children themselves. The figures given for $M$ are the means of several samples all taken during his first two admissions to Addenbrooke's Hospital. It will be noted that no abnormalities were found in the father, mother, or mother's sister and that both children had low concentrations of sodium in their serum, high concentrations of potassium, and very low 'total $\mathrm{CO}_{2}$ '. They also had concentrations of urea above the normal limits, but the plasma levels of inorganic phosphorus and creatinine in $\mathbf{M}$ were essentially normal.

Table 2 shows the averaged findings for the 24 hour urines of six normal adults before and after the administration of 2 to $2.5 \mathrm{mEq}$. of ammonium chloride per $\mathrm{kg}$. per day for five days. It also shows the results for the same test on the father and mother of the two children, and on the mother's sister. Results for some normal babies and some cases of juvenile renal acidosis are included; some of these have been taken from the literature. The results for $M$ are given in heavy type. Unfortunately those for the young child, $\mathrm{C}$, are limited. It will be seen that:

(1) The average $p \mathrm{H}$ for the seven normal persons on their customary diet was $5 \cdot 9$, and the percentage of the surplus anions excreted as ammonia, i.e. the ammonia $x$ $100 /$ ammonia + titratable acidity was 47 . This conforms with the findings of Marriott and Howland (1918), Van Slyke, Linder, Hiller, Leiter and McIntosh (1926) and of Linder (1927). In this paper the equivalent of the titratable acidity +ammonia will be referred to as the 'surplus non volatile anions', or simply 'surplus anions'; in the absence of urinary bicarbonate this is a measure of the excretion of acid or hydrogen ions.

(2) After five days on ammonium chloride the $p \mathrm{H}$ of the normal urines had fallen to $4 \cdot 6$, the titratable acidity had increased, but to a smaller extent than the ammonia, and the percentage of the surplus anions excreted as ammonium salts had risen to 64; this was in accordance with expectation (Davies and Yudkin, 1952; Rector, Seldin and Copenhaver, 1955; Ryberg, 1948).

(3) No abnormalities were detected in the father or mother. 
(4) The percentage of the surplus anions excreted by the mother's sister as ammonium salts on her customary diet may have been somewhat below the normal average, but it was not below the normal range and the response to an acid load was perfectly normal.

(5) The patients with renal acidosis were unable to achieve the normal acidification of the urine but the percentage of the surplus anions excreted as ammonium salts was quite normal.

(6) Both children were able to lower the $p \mathrm{H}$ of their urine to the normal extent, but the percentage of the surplus anions excreted by $M$ as ammonium salts was abnormally low. It was, moreover, consistently so. Only one figure above 30 was obtained.

\section{Post Mortem Findings}

Naked Eye Appearances. A post mortem examination was conducted in both children, but in greater detail on the older child and the account which follows is based upon findings in the latter except where the younger child $(C)$ is specifically mentioned.
There was nothing characteristic about the external appearances of either child. No abnormality was detected in the liver, gall bladder, bile ducts, spleen, portal vein or its branches. The same applies to the oesophagus, stomach, small and large intestine. The pancreas was of normal size in M's case but rather hard and the cut surfaces were very firm; the ducts were normal. All parts of the heart were normal; there was a normal distribution of the great vessels and their branches and the renal vessels were normal. The lungs of $\mathbf{M}$ showed tiny areas of collapse along the posterior borders but otherwise appeared normal; the air passages were lined by dry grey mucosa; the larynx, tonsils and middle ears were normal. As already mentioned the lungs of the young child $(\mathrm{C})$ were oedematous. The bones were macroscopically normal; the costo-chondral junctions, the right femur and an entire vertebral strip were inspected. The pituitary, thyroid, thymus and suprarenal glands were all normal.

The brain was highly abnormal. Small sunken areas of atrophy were present in gyri of the superior parts of the parietal lobes (Fig. 1). There was also conspicuous cerebellar atrophy. The cerebellum as a whole was

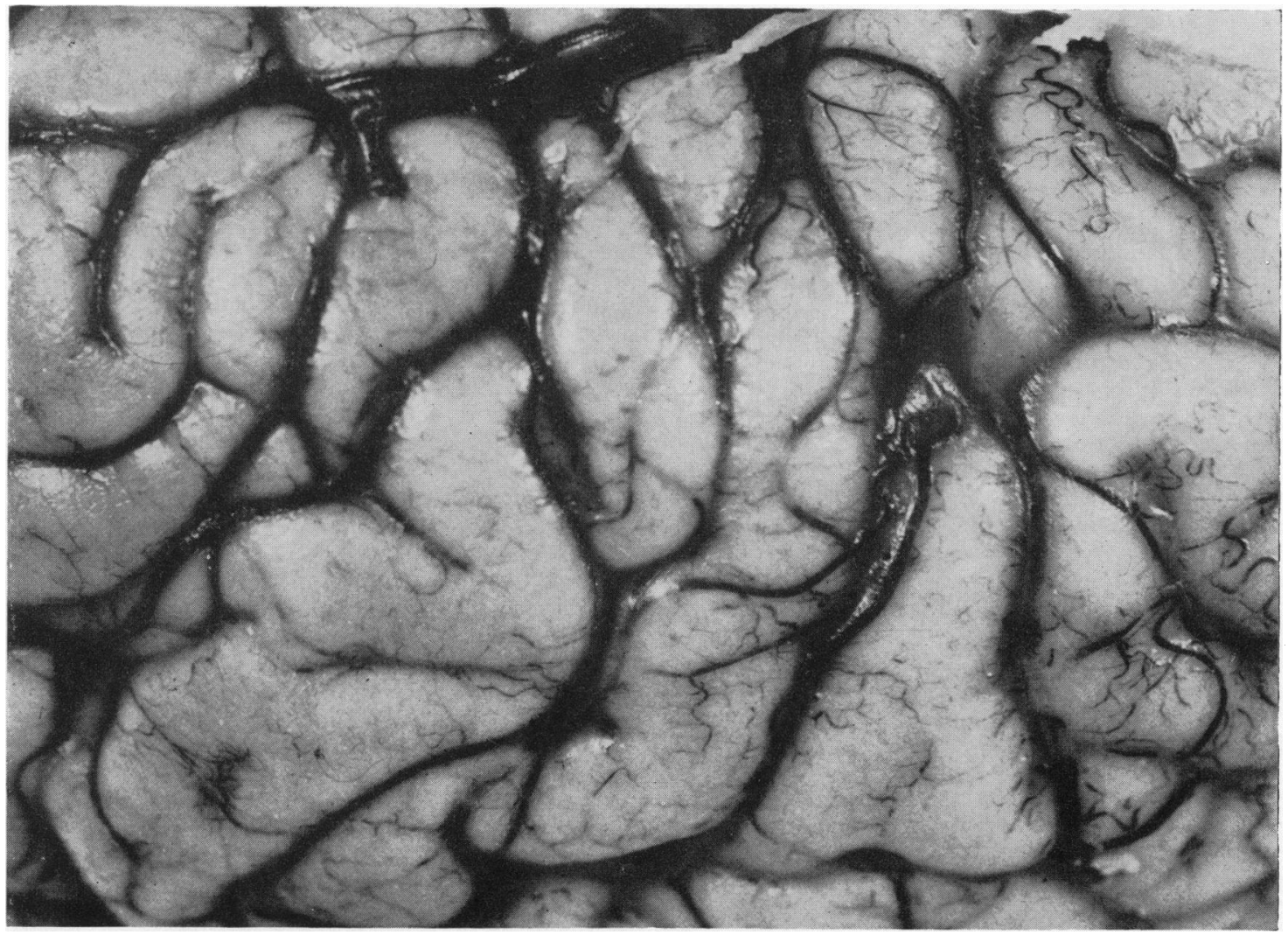

Fig. 1.-Parietal cortex of $\mathbf{M}$ showing a small area of atrophy. 


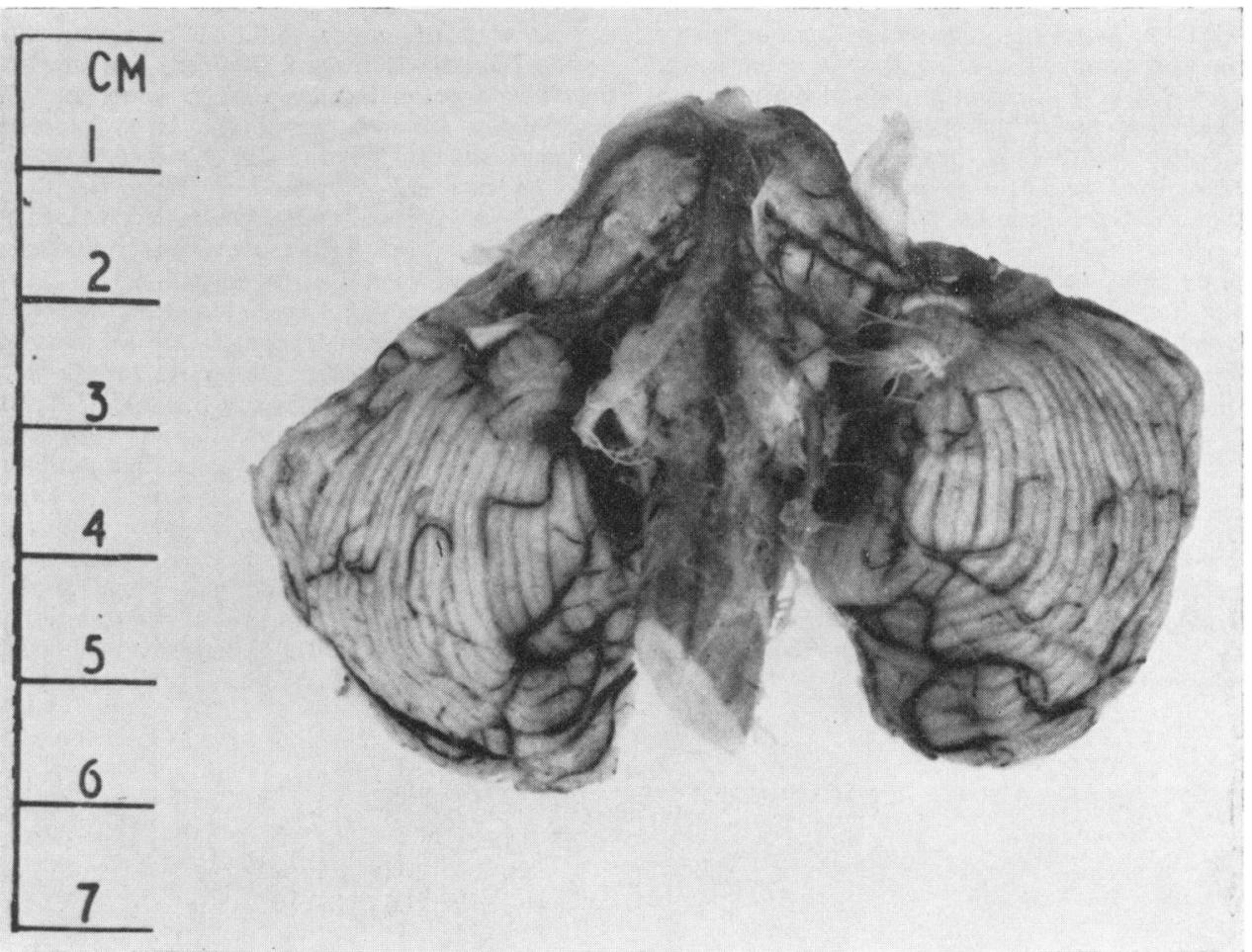

FIG. 2.-Cerebellum showing reduction of size and symmetrical areas of atrophy.

small, the folia being below the normal size and the vermis and nodule almost completely atrophic (Fig. 2). The cerebral veins and arteries were normal, however, as were the dural sinuses and meninges. No abnormality was found in the spinal cord.

Both testes were absent from the scrotum, nor could they be located in any of the usual ectopic sites; all that could be found were slight swellings on the spermatic cords near to the attachment of the gubernaculum to the scrotum. C had horseshoe kidneys but no other anatomical abnormalities. In M's case the renal cortex showed a curious yellow speckling and was of reduced width $(0.2 \mathrm{~cm}$.) compared with a control $(0 \cdot 5-0.6 \mathrm{~cm}$.) of the same age. The renal pelves, ureters, bladder and penis were normal.

Histological and Enzymatic Examinations. Pieces of tissue were taken from many of M's organs and fixed in $10 \%$ formaldehyde saline. Pieces of kidney, liver, pancreas, heart and brain were 'freeze substituted' in butanol and embedded in water soluble wax; these pieces were examined histochemically for the distribution of a variety of enzymes. Portions of C's kidney were preserved at $-15^{\circ} \mathrm{C}$.

The kidneys of both children showed the same abnormalities to a similar degree. Deposits of calcium were visible within epithelial cells in the distal parts of the tubules and in the loops of Henle, but the exact site was difficult to define. In M's case epithelial nuclei were outlined by rings of calcium, as they may be in the metastatic nephrocalcinosis due to acidosis or alkalosis. The glomeruli in the superficial zone of the kidneys were abnormally small. Apart from their size some were normal while in others the parietal layer of Bowman's capsule was thickened (Fig. 3a and b). No such appearance was found in controls. The renal vessels appeared normal in the sections. No other abnormality was found in the remainder of the urinary tract. Sections of the lower ends of M's spermatic cords showed the epididymis to be present but none of the sections revealed any evidence of testicular tissue. The nuclei in the skin and other tissues of the older child were chromatin negative, suggesting that the genetic sex was male.

The cerebellum showed small widely spaced folia with absence of a granular layer and the presence of numerous Purkinje cells, many of them within the molecular layer (Fig. 4). All contained abundant protein when stained by the tetrazo method (Fig. 5); gliosis was scanty in the granular layer. The pons, olives, dorsal and ventral spinocerebellar tracts were normal and so were the dentate nuclei. Sections of the cerebral hemispheres revealed a deficiency of neurones in the areas of microgyria but no other abnormality was found in sections from most parts of the brain and cord. The right eye 


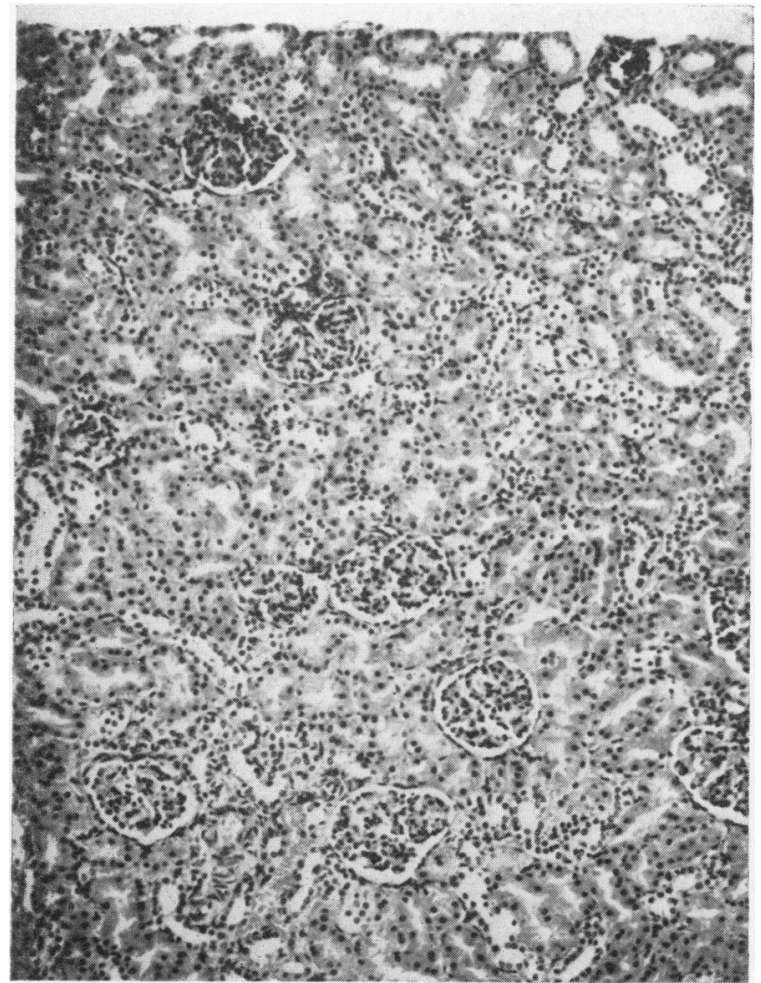

FIG. 3a.

Fig. 3a.-Section of a normal kidney from a child of the same age as $M$. ( $\mathrm{H}$ and $\mathrm{E} \times 115)$

Fig. 3b.-Section of M.'s kidney showing a superficial zone of small fibrotic glomeruli and enlargement of an adjacent nephron. ( $\mathrm{H}$ and $\mathrm{E} \times 115$ )

Fig. 4.-Section of M.'s cerebellar cortex. Note the absence of the granular layer and the necrotic Purkinje cells near the surface. (H and $\mathrm{E} \times 115$ )

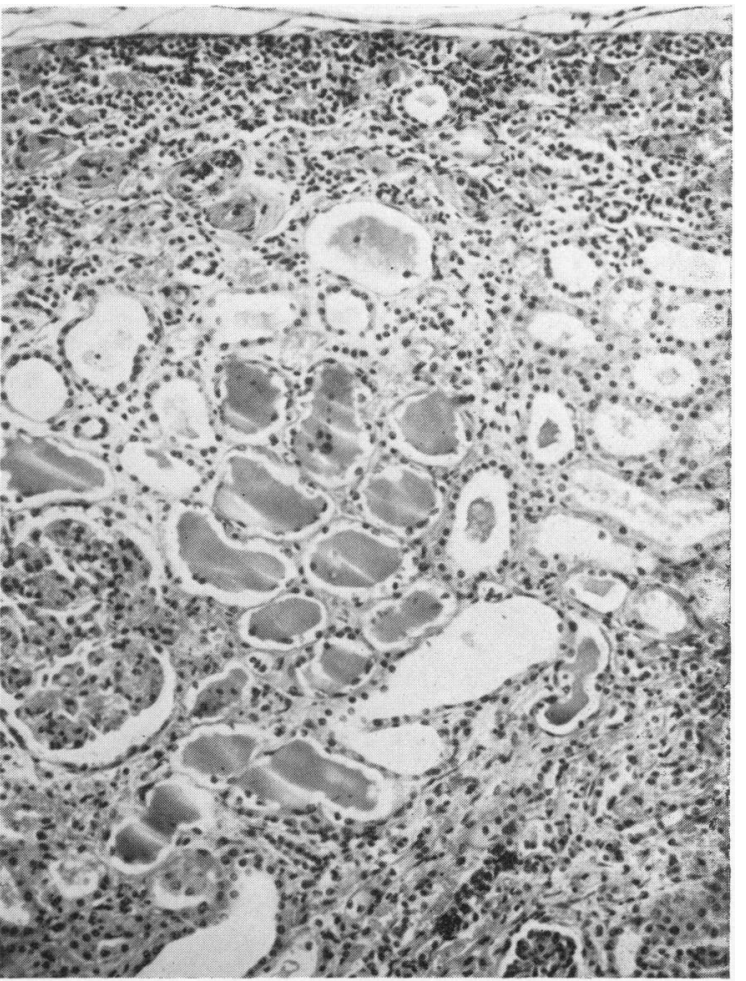

Fig. 3b.

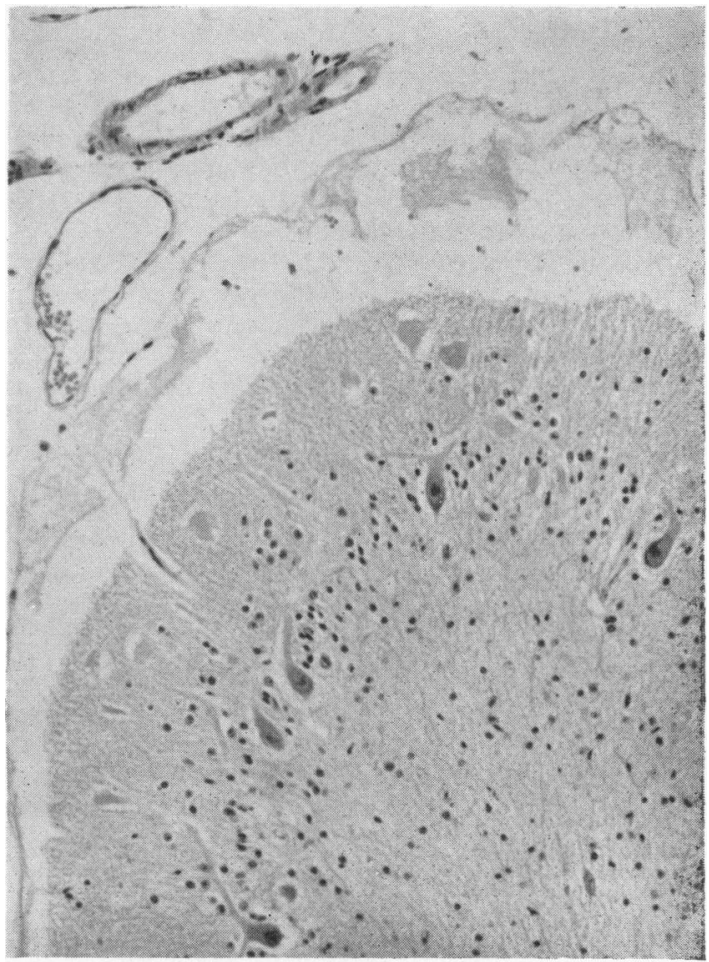

FIG. 4. 


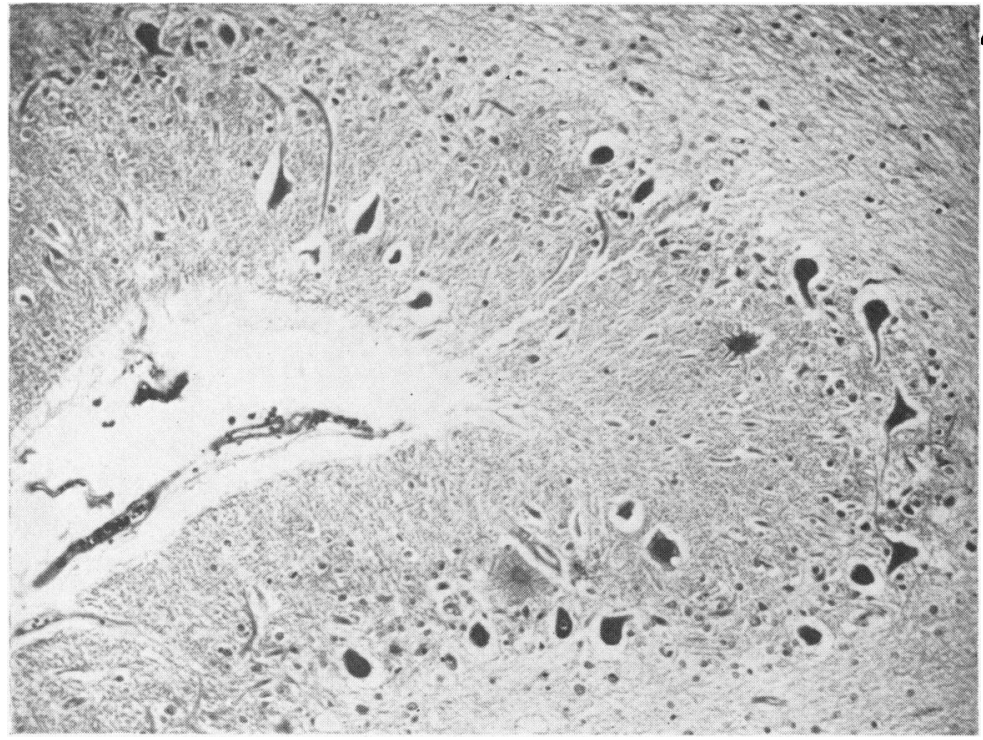

FIG. 5.-Asteroid structures in the cerebellar cortex. Abundant protein is present in both normal and dead Purkinje cells. (Tetrazo method for protein. $\times 115$ )

esterases were studied, but the only significant abnormality was the presence of acid phosphatase activity near to the deposits of calcium in the kidneys. An overall reduction of esterase activity was found in C's kidney associated with some spots of intense activity in certain cells. Portions of C's kidney were examined many months after the child's death for their glutaminase activity and the values found, which are given in Table 4, must be considered normal.

\section{Discussion}

The Differential Diagnosis. There is nothing really diagnostic about a disinclination for food and a failure to thrive which were the earliest causes of anxiety. Recognition of the mental retardation, corneal opacities, nystagmus and photophobia came later, as did the

was examined and some early corneal keratinization and vascularization were found but no other abnormality. These appearances in the cornea were similar to those which had been found in the cornea of the younger child $\mathrm{C}$.

Premature ossification was a feature in the columns of cartilage of the epiphyseal plates at the upper end of the femur (Fig. 6) (Harris, 1933).

No abnormalities were found during the histological examinations of various parts of the gut, and plasma cells were seen in moderate numbers in the lamina propria mucosae of the intestine.

All the lobes of M's lungs contained histological abnormalities: some of the veins had agonal thrombi in them, and many of the bronchioles and alveolar ducts contained vegetable debris, indicating that some of the stomach contents had been inhaled just before death and the occasional presence of foreign body giant cells suggested that inhalation of vomit had occurred previously.

Histochemical examinations of freeze substituted pieces of M's kidney, liver, pancreas and brain were made. Acid and alkaline phosphatases and non-specific

TABLE 4

THE GLUTAMINASE ACTIVITY OF THE KIDNEY OF THE YOUNGER CHILD AND OF A CONTROL OF ABOUT THE SAME WEIGHT

(see Radde and McCance, 1959)

\begin{tabular}{l|c|c}
\hline & mg. $\mathrm{NH}_{3} / 100 \mathrm{mg}$. dry matter/hour \\
\cline { 2 - 3 } & Patient & Control \\
\hline Without added glutamine & 103 & 84 \\
With added glutamine & 353 & 215 \\
\hline
\end{tabular}
severe reduction in the plasma bicarbonate, and

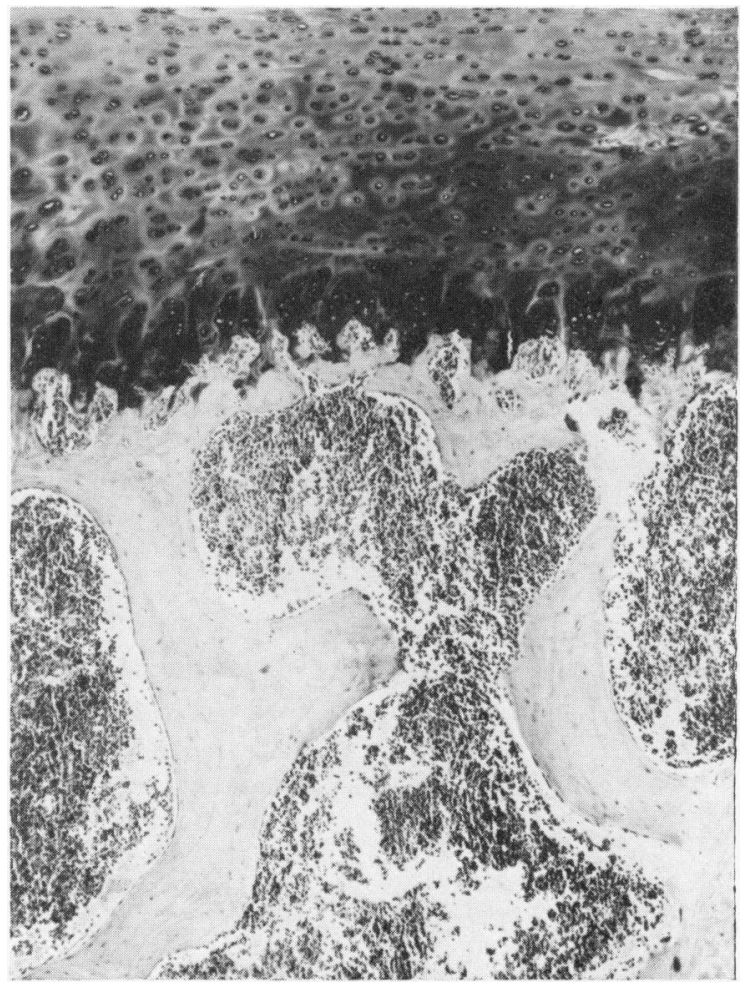

Fig. 6.-Section of M.'s upper femoral epiphyseal plate to show the arrest of growth. (H and $\mathrm{E} \times 45$ ) 
the raised blood urea. The highly acid urines, however, separate $M$ and $C$ from the children described by Lowe et al. (1952), and by Royer and Prader (1957) because all of the latter were apparently unable to acidify the urine and therefore were correctly diagnosed as cases of renal tubular acidosis (Stapleton, 1949; Doxiadis, 1952; Wilkinson, 1954). They were also excreting large amounts of organic-probably amino acids-in their urine (Jackson and Linder, 1953; Piel, 1957; Jonxis, 1957; Mudge, 1958). The present children were not, and the amino acid patterns of the serum and C.S.F. of the elder boy (the only one whose C.S.F. was tested) were also normal. These findings were taken at the time to rule out cystinosis, and this was again excluded by chemical and histochemical tests made on the tissues after death. Other records which were studied in making the differential diagnosis were those of Goldbloom et al. (1957). The disease in their cases had a different age of onset, and the patients suffered from nervedeafness and a lesion described as chronic interstitial pyelonephritis. These syndromes, like the present one, may be familial (Cooke and Kleeman, 1950; Rendle-Short, 1953; Schreiner, Smith and Kyle, 1953; Foss, Perry and Wood, 1956; Wrong and Davies, 1959).

It is frequently stated that patients with renal tubular acidosis are unable to excrete ammonia (Lowe et al., 1952; Lowe and Smith, 1955; Albright, Burnett, Parson, Reifenstein and Roos, 1946; Albright, Consolazio, Coombs, Sulkowitch and Talbott, 1940; Baines, Barclay and Cooke, 1945; Boyd and Stearns, 1942; McCune and Pray, 1940; Piel, 1957; Debré et al., 1955; Debré, Royer and Lestradet, 1956; Royer and Prader, 1957). Some authors have considered that there is no real interference with the formation of ammonia in this disease (Gabrielsen, 1954; Stapleton, 1949; Latner and Burnard, 1950; Wrong and Davies, 1959). With this the information given in the literature is really in agreement (see Table 2), although the patients may have been said to be unable to excrete ammonia. The patients of Lowe et al. (1952), for example, had perfectly normal $\mathrm{NH}_{3} / \mathrm{NH}_{3}+$ titratable acidity ratios in their urine; the figures given averaged over 0.6 , and there is no evidence that their kidneys could not have produced $\mathrm{NH}_{3}$ in normal measure if there had been any way of putting them under test by making the urine acid. There is nothing in renal tubular acidosis comparable to the findings in these two children in whose urines the ammonia formed less than $30 \%$ of the ammonia the titratable acidity even when the $p \mathrm{H}$ had been very low for weeks. This is the state of affairs originally described by Palmer and Henderson (1915) and Henderson and Palmer (1915), who reported that, in some patients with advanced chronic glomerular nephritis, the $\mathrm{NH}_{3} / \mathrm{NH}_{3}$ + titratable acidity ratios were subnormal. These findings have been confirmed by several investigators and the whole subject brought up to date by Schwartz et al. (1959) and by Wrong and Davies (1959). M was investigated when the concentration of urea in his plasma was still only $100 \mathrm{mg} . / 100 \mathrm{ml}$. or less, and his concentrating power reasonably good. The kidneys of both children were examined after death and neither of them had lesions in any way resembling chronic glomerular nephritis as had those of the children with a somewhat similar syndrome reported by Goldbloom et al. (1957). It was concluded therefore that a feature of our cases was a rather specific failure of the kidney to excrete ammonium ions-see Wrong and Davies (1959). Talbot, Sobel, McArthur and Crawford (1952) have described one patient who appears to have had a specific renal deficiency in the excretion of ammonia, but no others seem to have been recorded. Talbot et al. (1952) were interested in such patients mainly because the lesion might lead to the excretion of so much fixed base, particularly of calcium, that the patients developed osteomalacia. They therefore described their case in the section of their book dealing with the parathyroid glands, and the authors have informed us that contact with this patient has been lost.

The Normality of the Titratable Acidity. The excretion of a subnormal percentage of the total surplus anions as ammonium salts might have been caused by a very high titratable acidity in the urine due to the excretion of abnormal buffer substances. There was no evidence of this in $\mathrm{M}$ or $\mathrm{C}$, for the amino acids in the urine were normal in amount and type, and the quantities of phosphates excreted in the urine were enough to account for the customary percentage of the titratable acidity. Thus the average percentage for six normal adults was 65 after five days on ammonium chloride and M's average over three days, before being treated, was $75 \%$. The $p \mathrm{H}$ of the urines both in the adults and in $M$ ranged from 4.6-4.9. There is no evidence, therefore, that the titratable acidity was unusually magnified in quantity or form or that the $\mathrm{NH}_{3} \times$ $100 / \mathrm{NH}_{3}+$ titratable acidity was abnormal for this reason.

The Ammonia Coefficient. M's failure to excrete ammonia suggested an investigation of the percentage of his total nitrogen excreted as ammonium 
salts (the ammonia coefficient). This was very low, particularly when the $p \mathrm{H}$ of the urine was taken into account. Thus, out of a group of eight urines all with $p \mathrm{H}$ between $4 \cdot 6$ and 4.9, M's ammonia coefficient averaged only $1 \cdot 6$. The ammonia coefficient of the six normal adults averaged $3 \cdot 5$ when their urines had an average $p \mathrm{H}$ of $6 \cdot 0$, and the ammonia coefficient rose to $11 \cdot 5$ after five days on ammonium chloride.

The Nature of the Lesion. The lesions as a whole should probably be regarded as developmental failures, but the cerebral and cerebellar findings are unusual. Agenesis of the cerebral and cerebellar cortices usually leads to degeneration of the Purkinje and granular cells and extensive atrophy of the cerebral cortex (Norman, 1958). Furthermore the vermis and flocculi are usually normal, which they certainly were not in this case (Fig. 2). The cortical and cerebellar lesions appear not to have been neurologically associated since the pontine and dentate nuclei were normal, and no abnormality was detected in the cerebral peduncles or in the thalamus.

The cerebellar lesion is probably best considered as a developmental failure or early atrophy of cells in the granular layer, and if this is so the conspicuous involvement of the vermis is unusual (Ule, 1952). The suggestion is supported however by the asteroid like brushwork of fibres derived from Purkinje cells (Fig. 5); and another finding in favour is that the inferior olives were normal. The aetiology of cerebellar granular atrophy is in some cases familial (Norman, 1940) and usually associated with severe mental defect, as it was in this boy.

Both testes were absent and the case might, therefore, be classified as belonging to Klinefelter's syndrome in which mental abnormality, feeblemindedness and idiocy have been described by Ferguson-Smith (1958). Total absence of both testes is a decidedly rare anomaly. The finding of chromatin positive (Barr positive) nuclei neither supports nor refutes a diagnosis of Klinefelter's disease.

The other conspicuous abnormality lay in the kidneys, where the thin rind of small cortical glomeruli again suggests development failure, though it is just possible that some of the appearances might have been the result of pyelonephritis. The deposits of calcium and the occasional paratubular granulomata were probably sequelae of the metabolic disturbances which were such a feature during life. The high concentration of urea in the serum of both children indicates that their glomerular filtration rates were low. Determinations of $M$ 's endo- genous creatinine clearance were found to be $0.7 \mathrm{ml}$./ kg./min. on December 17, 1957 . Some lowering of the glomerular filtration rate in the absence of much, if any, histological sign of glomerular destruction is also in keeping with the large numbers of small and apparently undeveloped glomeruli in the peripheral parts of the cortex. It is just possible that the failure to excrete ammonium was functionally connected with these low glomerular filtration rates and not with any tubular lesion (Wrong and Davies, 1959), but M's glomerular filtration rates were not low enough in the early stages of his disease for this to be a very satisfactory explanation.

\section{Summary}

The following syndrome has been defined following its investigation in two brothers whose parents were unrelated and healthy.

Little desire for food from birth; failure to grow and thrive; later, vomiting and sporadic attacks of diarrhoea.

Corneal opacities, partial blindness and nystagmus.

Mental retardation, intention tremor and (in one sibling) convulsions.

Serum: 'total $\mathrm{CO}_{2}$ ' very low, sodium low normal, potassium over normal, phosphorus normal, urea in the early stages $80-100 \mathrm{mg} . / 100 \mathrm{ml}$., terminal stages $270 \mathrm{mg}$.

Urine: always sterile, highly acid. Sp. gr. 1017 or more in the early stages. $\mathrm{NH}_{3} \times 100 / \mathrm{NH}_{3}+$ titratable acidity abnormally low, but no reduction in the glutaminase activity of the kidney in vitro.

Normal response to acetazolamide (one test).

Death from progressive renal failure.

Post mortem: conspicuous structural abnormalities in the brain, slight keratinization and vascularity of the cornea. Some calcification of the kidney. Many small (perhaps undeveloped) glomeruli in the periphery of a narrow cortex and no testes.

The authors are grateful to a number of people for their help over this investigation, notably Professor C. E. Dent, Drs. D. Gairdner, A. G. E. Pearse, H. Bickel, E. M. Ward, I. Radde, J. M. Walshe, A. M. Barrett and E. M. Widdowson; Mr. A. L. McCurry, Mr. D. A. T. Southgate, Miss E. M. Colbourn and the ward staff of the two hospitals concerned.

\section{References}

Albright, F., Burnett, C. H., Parson, W., Reifenstein, E. C. and Roos, A. (1946). Osteomalacia and late rickets. Medicine (Baltimore), 25, 399.

(Baltimore), 25, W. V., Coombs, F. S., Sulkowitch, H. W. and Talbott, J. H. (1940). Metabolic studies and therapy in a case of nephrocalcinosis with rickets and dwarfism. Johns Hopk. Hosp. Bull., 66, 7.

Baines, G. H., Barclay, J. A. and Cooke, W. T. (1945). Nephrocalcinosis associated with hyperchloraemia and low plasmabicarbonate. Quart. J. Med., n.s., 14, 113. 
Boyd, J. D. and Stearns, G. (1942). Concomitance of chronic acidosis with late rickets. Amer. J. Dis. Child., 64, 594.

Cooke, R. E. and Kleeman, C. R. (1950). Distal tubular dysfunction with renal calcification. Yale J. Biol. Med., 23, 199.

Davies, B. M. A. and Yudkin, J. (1952). Studies in biochemical adaptation. The origin of urinary ammonia as indicated by the effect of chronic acidosis and alkalosis on some renal enzymes effect of chronic acidosis and al

Debré, R., Royer, P. and Lestradet, H. (1956). Les insuffisances congénitales du tubule rénal chez l'enfant. Sem. Hôp. Paris 32, 235/p7-254/p26.

, - and Straub, W. (1955). L'insuffisance tubulaire congénitale avec arriération mentale, cataracte et glaucome (syndrome de Lowe). Arch. franc. Pédiat., 12, 337.

Doxiadis, S. A. (1952). Idiopathic renal acidosis in infancy. Arch. Dis. Childh., 27, 409.

Ferguson-Smith, M. A. (1958). Chromatin-positive Klinefelter's syndrome (primary microrchidism) in a mental-deficiency hospital. Lancet, 1, 928.

Foss, G. L., Perry, C. B. and Wood, F. J. Y. (1956). Renal tubular acidosis. Quart. J. Med. n.s., 25, 185

Gabrielsen, L. H. (1954). Idiopathic renal acidosis. Acta paediat. Stockh., 43, 198.

Goldbloom, R. B., Fraser, F. C., Waugh, D., Aronovitch, M. and Wiglesworth, F. W. (1957). Hereditary renal disease associated with nerve deafness and ocular lesions. Pediatrics, 20, 241.

Harris, H. A. (1933). Bone Growth in Health and Disease, p. 6 et seq. Oxford University Press, London.

Henderson, L. J. and Palmer, W. W. (1915). On the several factors of acid excretion in nephritis. J. biol. Chem., 21, 37.

Jackson, W. P. U. and Linder, G. C. (1953). Innate functional defects of the renal tubules, with particular reference to the Fanconi syndrome. Quart.J. Med. n.s., 22, 133.

Jonxis, J. H. P. (1957). Aminoacidurie. Ergebn. inn. Med. Kinderheilk n.s., 8, 169

Latner, A. L. and Burnard, E. D. (1950). Idiopathic hyperchloraemic renal acidosis of infants (nephrocalcinosis infantum) Observations on the site and nature of the lesion. Quart.J.Med. n.s., 19, 285 .

Linder, G. C. (1927). The effect of mineral acid on acid-base regulation in health and in nephritis. Ouart. $J$. Med.,n.s. 20, 285.

Lowe, C. U. and Smith, R. T. (1955). Pyruvic aciduria in a patient with organic aciduria. Helv. paediat. Acta, 10, 220.

-, Terry, M. and MacLachlan, E. A. (1952). Organic aciduria decreased renal ammonia production, hydrophthalmos and mental retardation. Amer. J. Dis. Child., 83, 164.

McCune, D. J. and Pray, L. G. (1940). Nephrocalcinosis with chronic tetany. Amer. J. Dis. Child. 60, 993.

Marriott, W. M. and Howland, J. (1918). The influence of acid phosphate on the elimination of ammonia in the urine Arch. intern. Med., $22,477$.

Mudge, G. H.' (1958). Clinical patterns of tubular dysfunction. Amer. J. Med. 24, 785

Norman, R. M. (1940). Primary degeneration of the granular layer of the cerebellum: an unusual form of familial cerebellar atrophy occurring in early life. Brain, 63, 365.

- (1958). In Greenfield, J. G., Blackwood, W., McMenemey, W. H., Meyer, A. and Norman, R. M. (1958). Neuropathology, p. 339 et seq. Arnold, London.

Palmer, W. W. and Henderson, L. J. (1915). A study of the severa factors of acid excretion in nephritis. Arch. intern. Med., 16, 109 .

Piel, C. F. (1957). Diseases of the renal tubules in childhood. Pediatrics, 20, 337.

Radde, I. C. and McCance, R. A. (1959). Glutaminase activity of the foetal membranes and kidneys of pigs. Nature (Lond.), 183, 115.

Rector, F. C., Seldin, D. W. and Copenhaver, J. H. (1955). The mechanism of ammonia excretion during ammonium chloride acidosis. J. clin. Invest., 34, 20.

Rendle-Short, J. (1953). Idiopathic renal acidosis in twins. Alkalosis resulting from overdosage of a citrate mixture. Arch. Dis. Childh., 28, 55 .

Royer, P. and Prader, A. (1957). Les insuffisances congénitales du tubule rénal chez l'enfant. 16e Congrès des Pédiat. Langue Franc., 1, 263.

Ryberg, C.' (1948). On the formation of ammonia in the kidneys during acidosis. Acta physiol. scand., 15, 114

Schreiner, G. E., Smith, L. H. and Kyle, L. H. (1953). Renal hyperchloremic acidosis. Amer. J. Med., 15, 122

Schwartz, W. B., Hall, P. W., Hays, R. M. and Relman, A. S. (1959). On the mechanism of acidosis in chronic renal disease. J. clin. Invest., 38, 39.

Van Slyke, D. D., Linder, G. C., Hiller, A., Leiter, L. and McIntosh, J. F. (1926). The excretion of ammonia and titratable acid in nephritis. Ibid., 2, 255.

Stapleton, T. (1949). Idiopathic renal acidosis in an infant with excessive loss of bicarbonate in the urine. Lancet, 1, 683.

Talbot, N. B., Sobel, E. H., McArthur, J. W. and Crawford, J. D. (1952). Functional Endocrinology from Birth through Adolescence. Harvard University Press, Cambridge, Mass.

Ule, G. (1952). Kleinhirnrindenatrophie vom Körnertyp. Dtsch. Z. Nervenheilk., 168, 195.

Wilkinson, R. H. (1954). Some metabolic disorders. In Recent Advances in Paediatrics, ed. by D. Gairdner, p. 368. Churchill, London.

Wrong, O. and Davies, H. E. F. (1959). The excretion of acid in renal disease. Quart. J. Med. n.s., 28, 259. 